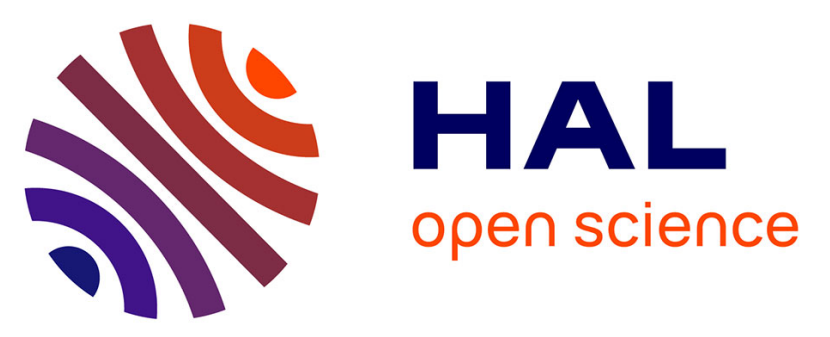

\title{
Does the African native host explain the African origin of the parasite? The Maltese Geckobia estherae n. sp. parasitic on Tarentola mauritanica (Acari: Raphignathoidea: Pterygosomatidae)
}

M. Bertrand, W.P. Pfliegler, A. Sciberras

\section{To cite this version:}

M. Bertrand, W.P. Pfliegler, A. Sciberras. Does the African native host explain the African origin of the parasite? The Maltese Geckobia estherae n. sp. parasitic on Tarentola mauritanica (Acari: Raphignathoidea: Pterygosomatidae). Acarologia, 2012, 52 (4), pp.353-366. 10.1051/acarologia/20122073 . hal-01567095

\section{HAL Id: hal-01567095 \\ https://hal.science/hal-01567095}

Submitted on 21 Jul 2017

HAL is a multi-disciplinary open access archive for the deposit and dissemination of scientific research documents, whether they are published or not. The documents may come from teaching and research institutions in France or abroad, or from public or private research centers.
L'archive ouverte pluridisciplinaire HAL, est destinée au dépôt et à la diffusion de documents scientifiques de niveau recherche, publiés ou non, émanant des établissements d'enseignement et de recherche français ou étrangers, des laboratoires publics ou privés.

\section{(ㅇ)(1) $\$$}

Distributed under a Creative Commons Attribution - NonCommercial - NoDerivatives $\mid 4.0$ 


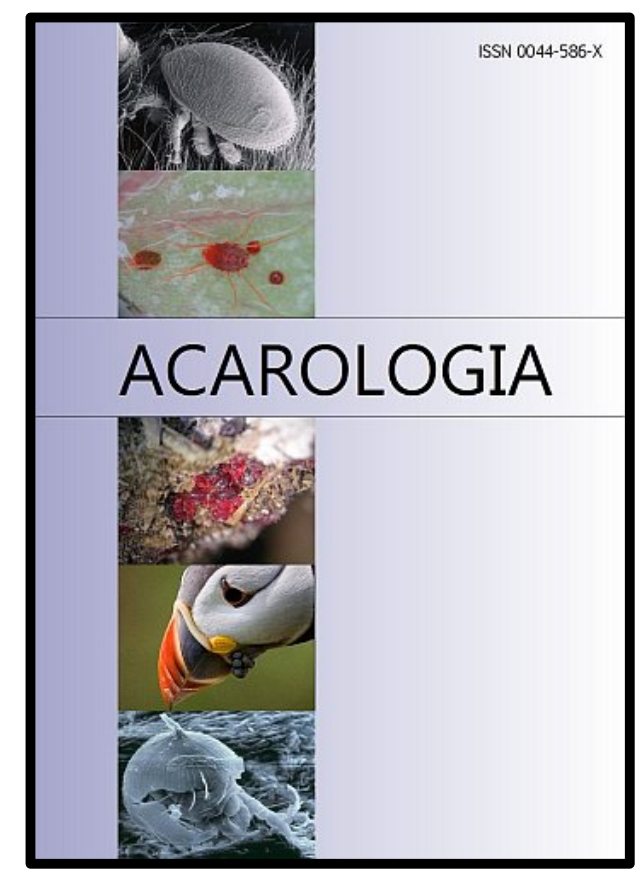

\section{ACAROLOGIA}

A quarterly journal of acarology, since 1959

Publishing on all aspects of the Acari

All information:

http://www1.montpellier.inra.fr/CBGP/acarologia/ acarologia@supagro.inra.fr

\section{OPEN ACCESS}

\section{Acarologia is proudly non-profit, with no page charges and free open access}

Please help us maintain this system by encouraging your institutes to subscribe to the print version of the journal and by sending us your high quality research on the Acari.

Subscriptions: Year 2017 (Volume 57): $380 €$ http://www1.montpellier.inra.fr/CBGP/acarologia/subscribe.php

Previous volumes (2010-2015): $250 € /$ year (4 issues)

Acarologia, CBGP, CS 30016, 34988 MONTFERRIER-sur-LEZ Cedex, France

The digitalization of Acarologia papers prior to 2000 was supported by Agropolis Fondation under the reference ID 1500-024 through the « Investissements d'avenir » programme

(Labex Agro: ANR-10-LABX-0001-01)
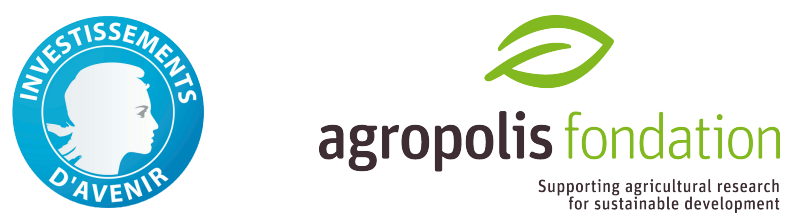

Acarologia is under free license and distributed under the terms of the

Creative Commons-BY-NC-ND which permits unrestricted non-commercial use, distribution, and reproduction in any medium, provided the original author and source are credited. 


\title{
DOES THE AFRICAN NATIVE HOST EXPLAIN THE AFRICAN ORIGIN OF THE PARASITE? THE MALTESE GECKOBIA ESTHERAE N. SP. PARASITIC ON TARENTOLA MAURITANICA (ACARI: RAPHIGNATHOIDEA: PTERYGOSOMATIDAE)
}

\author{
Michel BertrAnD ${ }^{1}$, Walter P. PfLIEGLER ${ }^{2}$ and Arnold SCIBERRAS ${ }^{3}$ \\ (Received 04 May 2012; accepted 20 August 2012; published online 21 December 2012) \\ ${ }^{1}$ UMR5175 CEFE, Université Montpellier 3, Route de Mende, 34199 Montpellier cedex5, France. michel.bertrand@univ-montp3.fr \\ (corresponding author) \\ ${ }^{2}$ Department of Genetics and Applied Microbiology, University of Debrecen, Egyetem tér 1., H-4010 Debrecen, Hungary. \\ walterpfliegler@gmail.com \\ ${ }^{3}$ Nature Trust (Malta) 133 'Arnest', Arcade Str, Paola, Malta. bioislets@gmail.com
}

\begin{abstract}
As in other geographic situations, Maltese populations of the common Mediterranean wall gecko, Tarentola mauritanica, were found to be simultaneously infested by two species of geckobians, Geckobia loricata and Geckobia estherae n.sp.. The latter species exhibits modified scale-like setae. The geckobians, protected ventrally by such scale-like setae, are widely distributed: in and around the Mediterranean Basin, these species were described notably on Phyllodactylidae (Tarentola). Most of them belong to the group I defined by Jack (1964) considering the leg chaetotaxy. The distribution of geckobians allied to the new species is discussed and correlated to the most recent knowledge on the genus Tarentola. The host being primarily African, the possible African origin and the dispersion by wall geckoes of these geckobians is discussed. As far as we know, such scaly species are not present in South or North America. The acquisition of this adaptation should therefore date from the early Cenozoic. The authors conclude that new investigations are necessary to examine this hypothesis on the Mediterranean gekkotans. Three identification keys are provided, a general key for the genera, one improved key for the identification of the groups of species of the geckobians, and the third for the described species with scale like setae.
\end{abstract}

KEYWORDS - Geckobia; Pteygosomatidae; Tarentola; Gekkonidae; parasites; host-parasite relationship; adaptation; biogeography

\section{INTRODUCTION}

"Delineating species boundaries is crucial because it is the first step toward discussing broader questions on biogeography, ecology, conservation, or evolution. The gap in communication between different disciplines currently related to species recognition is an important but often overlooked problem" (Carranza et al. 2002).
With few exceptions, the Pterygosomatidae (often called as "scale mites") are specialist parasites of reptiles. These blood suckers spend more than $90 \%$ of their lifetime fixed deeply by their chelicerae on the host's teguments. If the most primitive genera are not greatly modified by the parasitic way of life (Pimeliaphilus, Hirstiella and Geckobiella), the others have integrated the constraints of life on a type of host and are highly specialized: the diverse Geck- 
oes are targeted by the genus Geckobia, the Agamidae by Pterygosoma spp.

In this article, the new Maltese species Geckobia estherae n. sp. found on the common wall gecko is described. It was the opportunity to complement (and to interrogate on) the larger question of the links between the genus Tarentola L., 1758 and the geckobians in the Mediterranean Region. Recently, the phylogenetic classification of Gekkotans integrated new analysis and discriminates now the Phyllodactylidae (i.e. genera Tarentola, Phyllodactylus) from the Gekkonidae (Gamble et al. 2008a, 2010). These two families diverged during the Mesozoic (Vidal and Hedges 2009). The genus Tarentola (around 20 species) belongs to the Phyllodactylids. All species are robust, without divided subdigital lamellae, and well-developed claws on the third and fourth digits and, with a unique exception, have a conservative morphology (Carranza et al. 2002). The genus Tarentola sensu stricto is distributed in North Africa, southern Europe, and the eastern Canary Islands. The Linnaean species "Tarentola mauritanica" can be regarded now as a complex of species and subspecies with an African origin (Harris et al. 2004, Jirku et al. 2010); the parasitic geckobians have been described several decades ago, and by tradition, the two species collected on it are identified as Geckobia latastei Mégnin, 1878 and G. loricata Berlese, 1892 (Haitlinger 2004, Willmann 1955). However, new endemic geckobians were described on neighbor and insular host species, notably in Canary Islands (Zapatero-Ramos et al. 1989).

The collect of the new species in Malta is an original data. It permitted to verify: (i) that two geckobian species are hosted, by Tarentola mauritanica in different part of its distribution, (ii) that the two species, as in other situations, differ greatly each other, (notably by presence or absence of special shaped ventral hairs), and (iii) to interrogate on the correspondence of endemic hosts and the consequences for parasites around the Mediterranean Basin.

Two new questions are expecting answers, consecutively to the new data on host's origin and diversity: i) Why is it possible that, repeatedly, two so similar parasites share the same host? May be because the parameters of infestation by two species respectively with normal and scale like ventral setae differ? This problem was already investigated by Girot (1969).

ii) Can we reckon that the presence of highly modified ventral setae reveals a possible common origin of the Geckobians exhibiting this character, at least among the species parasitizing the host Tarentola spp.?

\section{MATERIAL AND METHODS}

Mites were collected on one male and two females (altogether 3 specimens) of the hosts, on the back of their heads, with spraying a small amount of surgical spirit onto the geckos body and then removing mites with a pincer. Some mites were cleared in lactic acid, and dissection of mouthparts and legs were done. Microscopic observation was helped by a microscope Wild Leitz $20 \mathrm{~EB}$, measurements (in $\mu \mathrm{m})$ were made on pictures taken with calibrated Motic camera and drawings were made using a camera lucida. Nomenclature follows Jack (1964), and Bertrand et al. (1999).

The Maltese herpetofauna: The only two Maltese geckoes (called "Wizgha" in Maltese language) are Hemidactylus turcicus and the Maltese wall gecko T. mauritanica. The present herpetofauna list of the Maltese islands consists of only sixteen species, of which five are marine turtles. Besides the mentioned geckoes, the terrestrial reptile species are four species of Colubridae, one Chamaeleontidae, one Scincidae and one endemic Lacertidae, with several subspecies. Two Amphibian species occur, a native frog from the Discoglossidae and one introduced species from the family of Ranidae (Sciberras, 2007). The only possible hosts are the Phyllodactylidae Tarentola and the Geckonidae Hemidactylus.

The host belongs to the genus Tarentola, the Mediterranean geckos, widely distributed. It is an African native genus: "Tarentola is generally very uniform and may have been so for over 10 million 
years; this is not due to any overwhelming phylogenetic constraint" (Carranza et al. 2002). Around the Mediterranean Sea, Tarentola is represented by several species and some subspecies have also been described: to date, the nominative subgenus comprises several endemic species: Tarentola mauritanica (Linnaeus, 1758); T. deserti Boulenger, 1891; T. angustimentalis Steindachner, 1891; T. boehmei Joger, 1984 and T. fascicularis Daudin, 1802.

\section{DESCRIPTION}

\section{Geckobia estherae n. sp.}

Parasitic on Maltese wall geckos Tarentola mauritanica (Linnaeus, 1758).

Holotype female. Locus typicus: Wied Encita, near Attard, Malta. The habitat was mostly abandoned farmland surrounded with rubble walls and with species among others, Ceratonia siliqua, Opuntia ficus-indica, Hedysarum coronarium, Ricinus communis, Nicotiana glauca, Arundo donax and Olea europea.

Deposit: in the Muséum National d'Histoire Naturelle de Paris (MNHN) Collection of Arthropoda. Holotype: female from sample Sciberras 20.X.2010, Malta. Paratypes. 4 females in MNHN Paris. No male was found.

Female - Twelve specimens. Body roughly triangular in shape, red colored, wider than long, rather small in size, length and width of animals preserved in ethanol: $260-290$ long, $480-490$ wide. Soft cuticle, covered by long and scarcely dense setae on the dorsum ranging from $25 \mu \mathrm{m}$ to $75-80 \mu \mathrm{m}$ in length.

Dorsal view (Fig. 1a) - Dorsum: cuticle with striation, covered by pilose setae (ca. 100 dorsal without scutal and lateral setae) longer on the central and peripheral parts than on the anterior. The scutum (Figs. 1a, 2a) is symmetric, clearly wider than long, generally with incised backward arbelos shape, centrally concave backwards. The scutum does not reach the slightly concave anterior edge of the body. Posterior to the frontal edge of the scutum, a double pair of setae is present. Ocular lenses are situated on a small latero-anterior extension of the scutum. Three paired lateral scutal setae, placed in rows all along the lateral limit of the scutum, four pairs of mediolateral setae and four pairs of setae along the concavity of the posterior limit of the scutum are present.

Dorsal setae, (more than 60 excluding peripheral and scutal setae) fairly elongated, are arranged in files symmetrically on each side of the body with a four setae file (each $60-75 \mu \mathrm{m}$ long) in the median part of the dorsum. Medially the anogenital fields are visible with three short anal setae (30 $45 \mu \mathrm{m})$ and three longer perigenital setae $(75 \mu \mathrm{m}$ in length)(Fig. 1d).

Ventral view (Fig. 1b) - Epimeral plates: Coxae are developed, gathered in two groups with setation from I to IV: 4(=2-2)-5(=3-2). Anterior epimeral plate (coxae I \& II): one thin and long setae (coxa I) $(>40 \mu \mathrm{m})$, the external seta shorter, two robust paraxial stout setae $(29-32)$. Posterior epimeral plate (coxae III \& IV) with five long and large epimeral brush-like setae $(>30 \mu \mathrm{m})$, subequal in length. The anterior and posterior epimeral plates are well separated by striated cuticle bearing two or three robust setae $(22 \mu \mathrm{m})$.

Ventral surface is covered by several differently shaped types of setae (Figs. 2c, 3):

i) in anterior position, at the same level than the first pair of coxae and between the right and left coxae and near the posterior end of the infracapitulum a row of four robust brush-like setae,

ii) a row of $14-18$ setae, shorter $(20 \mu \mathrm{m})$ and briefly ended, and at least some longer setae $(25-34 \mu \mathrm{m})$,

iii) the scale-like setae occupying the major surface of the central part of the venter, arranged in tiles, softly sharpened at the extremity and with irregular edges.

iv) usual setae, barbed and briefly ended distally.

Gnathosoma - Infracapitulum: In ventral view (Fig. 1c), the infracapitulum is subquadrangular in shape with one pair of long setae (= gnathobasal setae) slightly longer than the palp that can reach 100 

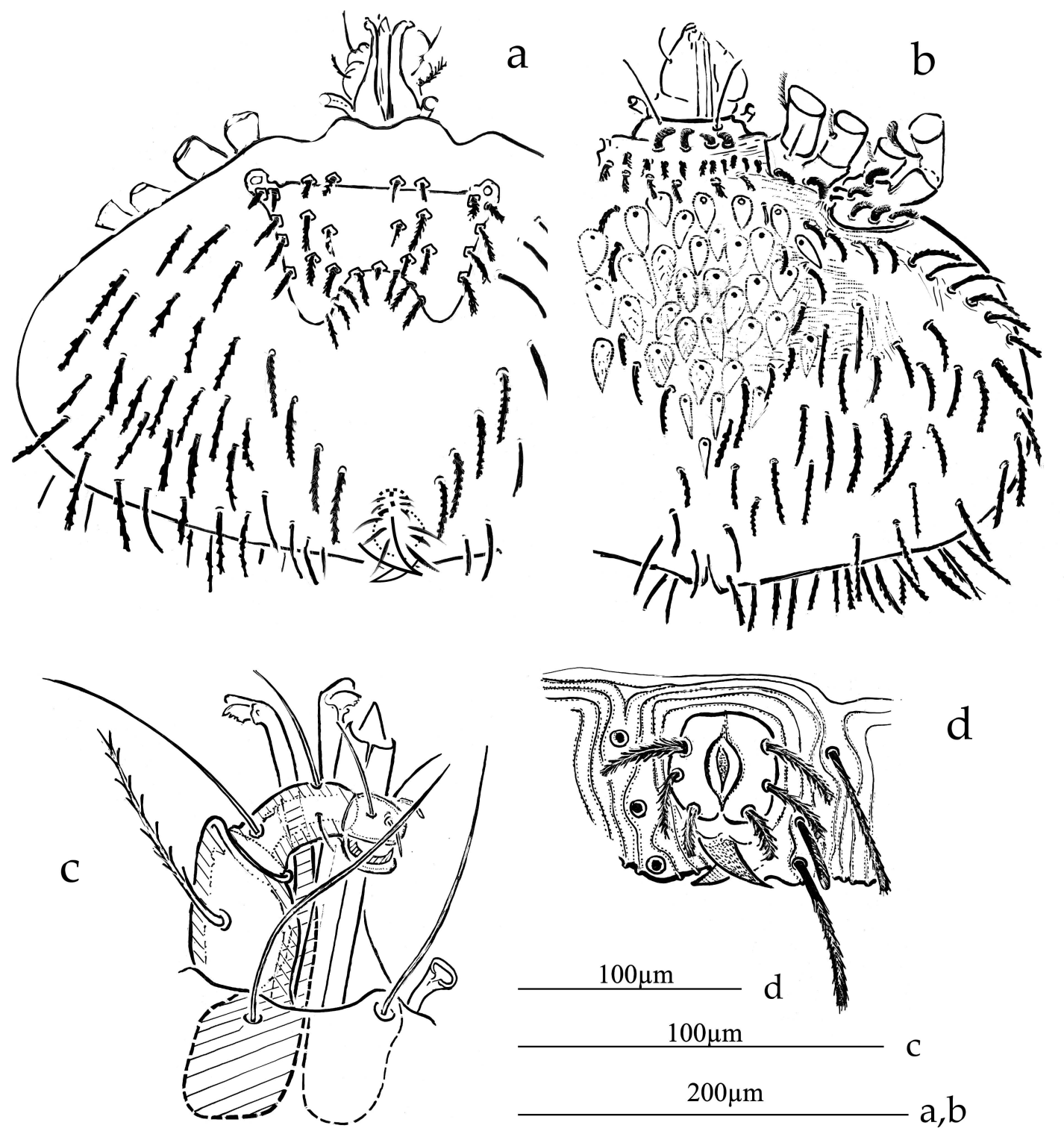

FIGURE 1: Geckobia estherae n. sp., female: a - Dorsal view female; b - Ventral view; c - Infracapitulum, palp and chelicerae, ventral view; $\mathrm{d}$ - Anogenital area (some setae are only represented by the base). 


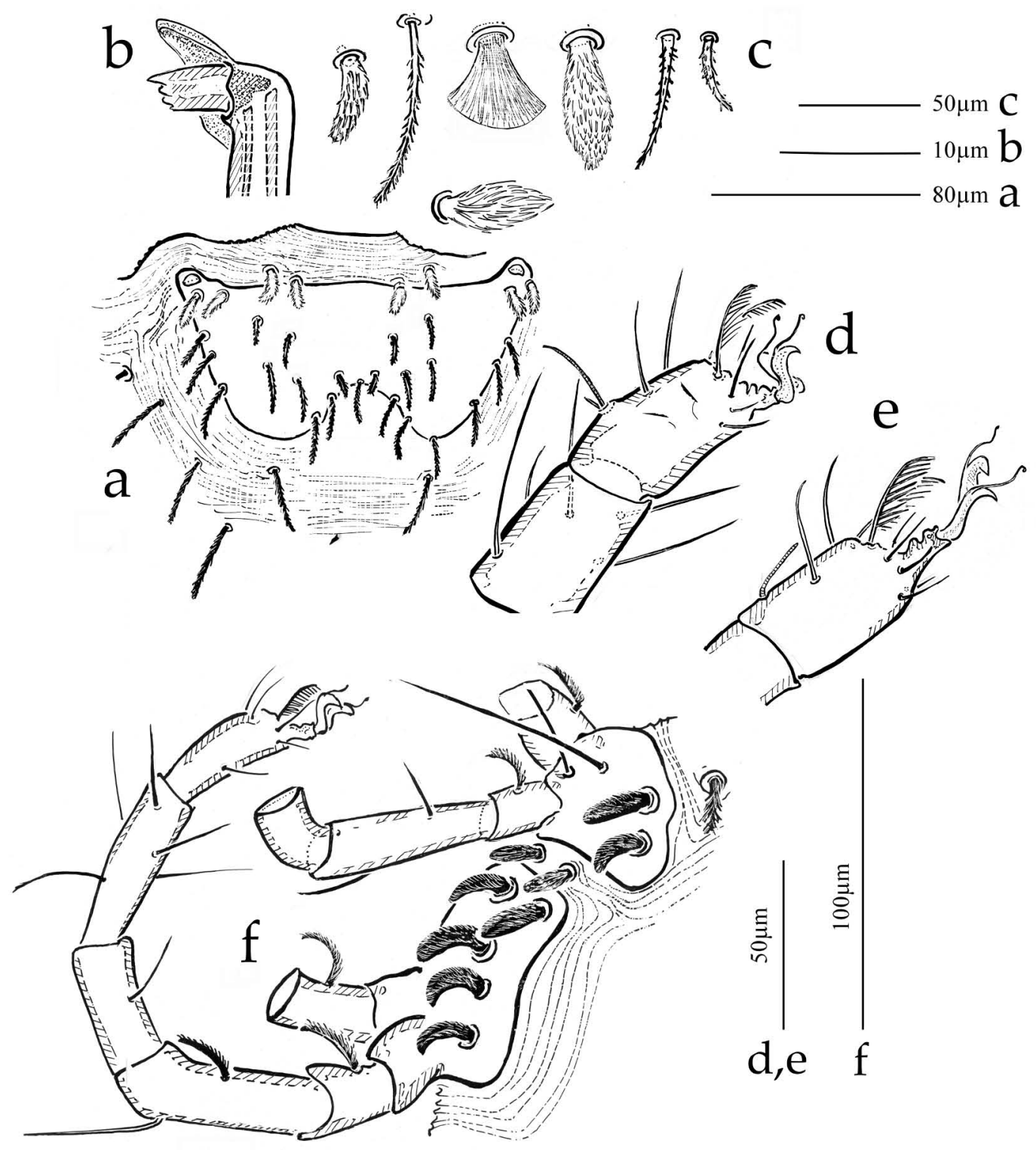

FIGURE 2: Geckobia estherae n. sp., female: a - Scutum and ocular lenses; b - distal part of left chelicera; c - Different shape of body setae: from left to right: scutal and dorsal setae, and four shapes of ventral setae, below: coxal setae; d-e - Tarsi I and II; f - Epimeral plate ventral view and leg IV. 


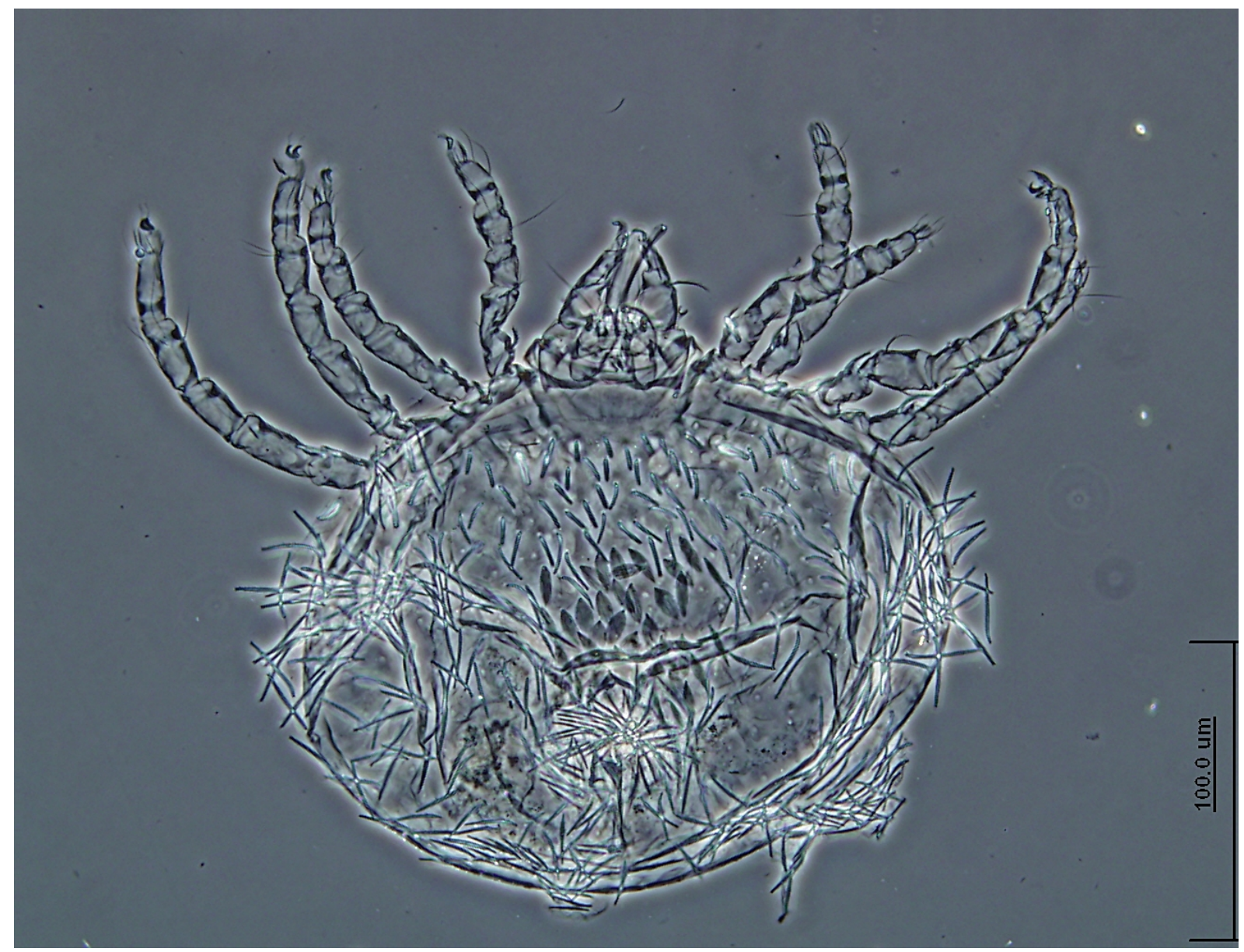

FIGURE 3: Geckobia estherae n. sp. General and ventral view (picture from W. Pflieger)

$\mu \mathrm{m}$ length. In dorsal view, the pedipalps (ca. $100 \mu \mathrm{m}$ long), the chelicerae $(>120 \mu \mathrm{m})$ and the lips tube are visible, flanked by the peritremes, directed upward. Chelicerae are 100-120 $\mu \mathrm{m}$ long. The proximal end $(30-40 \mu \mathrm{m})$ is subquadrangular in shape; it continues in a long slender branch ended by the mobile digit abruptly ended by $1-4$ little teeth protected by an incomplete hood (Fig. 2b). Palpi: femora are as long as wide, the femoral dorsal setae are ciliate, shorter than the dorsal seta of genua that is simple. Palpal chaetotaxy is 1-1-2-4 $+\omega$. Dorsal tibial seta is rather long compared to other species, but distinctly shorter than femoral and genual ones. The two longest setae of tarsus are $25-30 \mu \mathrm{m}$ long. The terminal claw is rather long, embedded and protected by a developed cuticle fold.

Legs - The shorter legs are the leg I and II (140 -
$160 \mu \mathrm{m}$ long $)$ the longer are III and IV $(200-250 \mu \mathrm{m}$ long). Separations between coxae I and II and coxae III and IV are not visible. Only the setae on coxae I are simple and long $(40-60 \mu \mathrm{m})$. On some specimens, the distal seta on coxa I was not observed. Other setae are stout and short (ca $25 \mu \mathrm{m}$ long). Coxal chaetotaxy $=4$ or $3(1$ or $2+2), 5(2+3)$. Anterior and posterior epimera are well separated and a file of two setae similar to the stout setae of coxae II and IV are situated on this inter-epimeric space.

Tibial, genual, and femoral setae are simple except on the fourth pair of legs; this ventral femoral seta is plumose. All trochanteral setae are plumose and strong.

Leg chaetotaxy remarkable by the long and ciliated ventro-lateral seta on each trochanter $(20-30$ $\mu \mathrm{m})$. Chaetotaxy from trochanter to tibia is (1-1- 
1-1) (3-2-2-2) (1-0-0-1) (5-5-5-5). This pattern corresponds to the Group I defined by Jack (1964). Femora I, II, III, IV with simple setae with the exception of the ventral seta of femur IV which is ciliate. Dorsal macrochetae $(41-42,62-69)$ of tibia I and IV are located behind the lateral setae (paraxial and antiaxial), dorsal setae of tibia II and III are in front of nearest and not too much longer $(27-36,34-36)$. Tarsi I and II (Figs. 2d,e) are short $(50 \mu \mathrm{m})$, snub, whereas tarsus IV is a bit elongated. (Fig. 2f) The dorsal solenidia $\omega_{2}$ of tarsi II visible. On tarsi I, two solenidia: the short solenidion $\omega_{1}(7-8 \mu \mathrm{m})$ with the companion seta alm (28-29 $\mu \mathrm{m}$ long). Tarsus I with usual setation: $m d,(b v),(t d),(t l d),(t l v)$ and characteristic $(t d f)$ well visible, only the ventral setae are ciliate. Setation of tarsus II: $(b v),(t d),(t l d),(l v t)(t d f)$ $+\omega_{2}$. The claws are projected forward on elongated ends of the tarsi. Tenent hairs with flattened ends present, two by unguis, the external branch being the longest.

Male - no male was collected.

Etymology - Species named in honor of Mrs. Esther Sciberras who assisted in the collection of the specimens and data during the field works and supported the herpetological works of Mr. Sciberras for years.

With the species here described, a second species was found on the Maltese wall-geckoes determined as G. latastei Mégnin, 1878, a common parasite of Tarentola spp. The latter species was already recorded from several countries (Spain, Balearic Islands, Morocco, Italy or France...) (Girot 1969, Haitlinger 2004, Hirst 1926, Willmann 1955, Zapatero-Ramos et al. 1989).

\section{Discussion on the diagnosis}

Geckobia estherae n. sp. is clearly identifiable by several characters:

1. The body shape, wider than long (character shared with G. tarentulae Trägårdh, 1905 and G. tinerfensis Zapatero-Ramos et al., 1989).

2. The scutum, symmetric W-shaped posteriorly (analogous shape to G. diversipilis Hrist, 1926), contrarily to G. loricata and canariensis
Zapatero-Ramos et al., 1989 (scutum soft, less visible except by cuticle striation, obsolescent in G. tinerfensis). Twenty six scutal setae with twelve pairs of scutal setae symmetrically disposedf, and the ocular setae near the lenses (versus 12 scutal setae, 6 pairs for G. loricata and tinerfensis).

3. The femoral palpal seta is long and ciliate, differs from the stronger and ciliate ones in the species described from Canary Islands; robust, slender and ciliate, it is less long in G. tarentulae and G. loricata. The ocular sclerites are fused anterolaterally to the scutum in prolongation with the anterior angles of the scutum (individualized from the scutum in the $\mathrm{Ca}$ nary species and $G$. loricata). The ventral scalelike setae are "crenellate" as in G. turkestana (Hirst 1926), but neither heart-shaped (G. loricata, G. turkestana) nor fan-shaped (G. tarentulae), nor elongated in length (G. hindustanica Hirst, 1926). They are replaced with shortened setae (brush-like) from the center of the venter towards the lateral sides. As previously observed on several species (G. turkestana, G. loricata, G. squamaeum Bertrand et al. 1999 and G. parvulum Bertrand et al. 1999 : Hirst 1926; Girot 1969; Bertrand et al. 1999), the shape of the peripheral setae changes gradually to become more and more elongated, first to "leaf-like setae" before making place to normal, "seta-like setae". A proximal tomentous and stout seta and a second, shorter one distally are present on epimera II. Regarding leg chaetotaxy the species belongs to the first group in Jack's nomenclature.

4. G. sarahae n. sp. possesses three femoral setae on leg I. This character is shared notably by G. loricata, G. turkestana and G. gymnodactyli Womersley, 1941 (this latter species on Nactus sp. or Phyllodactylus sp. in Australian Region). However, this character discriminates this species from G. parvulum (only 2 setae on femora). To help in identification we have updated and improved the general key previously published (Bertrand et al. 2008). 


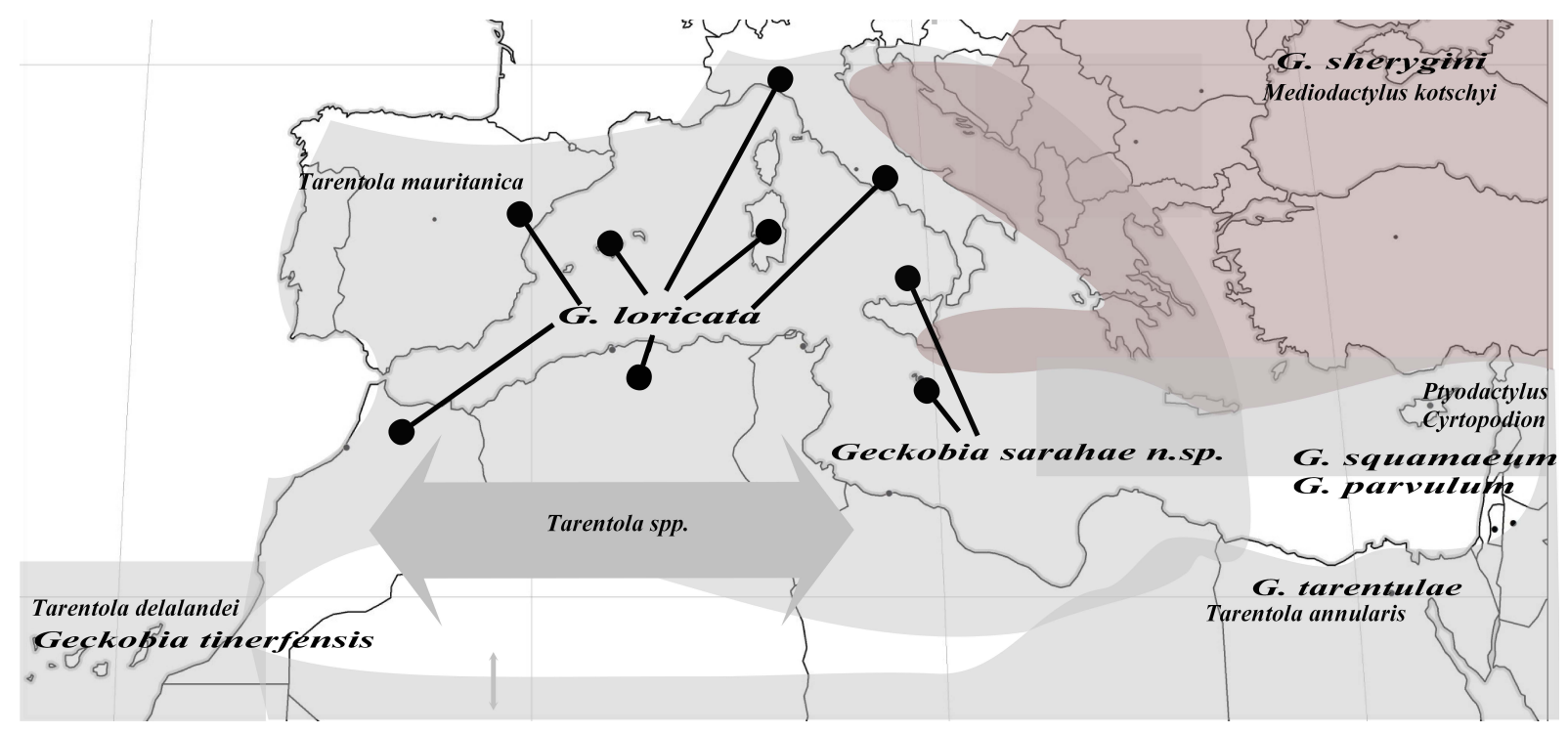

FIGURE 4: The geckobians with ventral scale like setae and their host in Mediterranean Region.

\section{DISCUSSION}

G. estherae n. sp. is parasite on T. mauritanica in Malta. In the past, it could have been confused with G. loricata. Among the species found on Tarentola sp., several species with ventral scale-like setae have been described. These species are distributed from Egypt to the Canary Islands (Fig. 4). Is it possible that some species have been misidentified? Certainly: Girot (1969) has questioned the identities of the two mites parasitic on Tarentola mauritanica: he noted a possible misidentification by the French naturalist Goux (1947) that described the development of "G. loricata", the venter of which being covered by scale-like setae. Girot contested Goux's identification: this mite originated from insular population studied from small islands around Sicilia (Isola de Ustica) and was fixed itself on the reptile's legs and not on the ventral scales (contrarily to G. loricata), and differed notably by the ventral setae, the number of inter-epimeral setae.

Since 1969, the identity of Girot's material, the Moroccan species of Tarentola, was enriched by subspecies descriptions (Geniez et al. 1999). Evidently, fifty years later, we can suspect that the parasites of the genus Tarentola were poorly investigated in regard of their putative diversity on the host complex: three species have been described from the West- ern Mediterranean Basin: G. loricata Berlese, 1892, G. latastei Mégnin, 1878 on T. mauritanica and G. tarentulae Trägårdh, 1905 on T. annularis in Egypt. G. canariensis Zapatero-Ramos et al., 1989 and G. tinerfensis Zapatero-Ramos et al., 1989 on T. delalandii Duméril et Bibron, 1836 were described from the Canary Islands. With exception of G. latastei, all these species present a part of the ventral surface covered by scale like setae. In this context, the collection of an original Geckobia on the Maltese population of T. mauritanica is a new step in the understanding of the geckobians parasitic on the wall geckoes complex in the Mediterranean Region.

Some other geckobians exhibit scale like setae as well: they were found on Gekkonidae, all from the Old World. Their presence coud be explained by overlapping niches of the hosts and contamination.

Since the Mesozoic, the modern geographic distribution of the phyllodactylid's parasites has seen different waves of colonization by the Phyllodactylidae, the rhythm being given by the different Mediterranean crisis. In the state of the present knowledge, we know that (Carranza et al. 2000):

i) the subgenus Neotarentola reached Cuba up to 23 million years ago,

ii) the subgenus Tarentola invaded the eastern Canary Islands more recently covering a min- 
imum of $120 \mathrm{~km}$. The subgenus Makariogecko arrived to Gran Canaria and the western Canary Islands 7-17.5 million years ago, and a single species of Makariogecko from Gomera or Tenerife in the western Canaries made the $1400 \mathrm{~km}$ journey to the Cape Verde Islands tip 7 million years ago by way of the southrunning Canary current.

The only Geckobians with ventral scale-like setae, and parasitic on Tarentola are distributed around the Mediterranean Sea, on the Mediterranean Islands, and the Canary Islands. Such setae were never observed of American geckobians (eg. G. leonilae Hoffmann and Morales-Malacara, 1985 and confirmed by Dr Ricardo Paredes-León, specialist of American Pterygosomatidae and curator of collections in Mexico). At least 5 points are of great interest:

1. The special ventral setae are apomorphies shared by the parasites of the African genus Tarentola and of the eponymous subgenus.

2. These species are classed into the Jack's first group defined by leg chaetotaxy.

3 . The coxal setae of these species are homogenous in shape, stout and brush like (epimera $2,3,4)$.

4. The solenidiotaxy is identical on the tarsi I and II.

\section{Eyes are present.}

Because the host Tarentola mauritanica is now subdivided in several endemics and vicariants, we should consider realistic the drift of the fragmented host populations that determined analogous drift of the parasitic organisms. The early colonization of the New World by Tarentola's lineages could explain the absence of "New World geckobians with scale-like setae", because the African native Phyllodactylids migrated too recently to expand the lineage of the parasites, a current character of insular colonization.

In conclusion, it is highly probable that during each journey, the African Phyllodactylids have carried and disseminated the parasites, and that the parasites speciated to survive whereas the hosts differentiated. In the Mediterranean region, populations of T. mauritanica were examined including the molecular approach: a new species and subspecies were described from Tunisia (Joger and Bshaenia, 2010). The analysis of the parasitic mites bore by each of these populations should update the specific parasites for each host, species or subspecies The analysis should confirm or not if G. latastei (the second common species, widely distributed in Mediterranean Region) was submitted to the same process. Geckobia latastei and G. loricata are common in Morocco, Spain (Gil-Collado et al., 1985), France, Italy (Berlese, 1892), and Western Mediterranean Islands (Corsica, Balearic Islands...). If we try a synthesis of the knowledge, we know that:

a) The genus Geckobia Mégnin, 1878 is specialized on the Gekkotans, everywhere the Geckkoes are present, and the main rule regarding hosts seems to be the geckobian's stenoxeny. Briefly, two cases can be observed, that are conform to the current knowledge (Boots et al. 2009). (i) when some hosts extended their distribution as the invasive geckoes did, the endemic native geckoes have kept their parasites (Martinez Rivera et al. 2003, Bertrand et al. 2008). (e.i. the genus Hemidactylus: Bertrand and Ineich 1989, Bochkov and Mironov 2000; Domrow 1983; Martinez Rivera et al. 2003). (ii) On the endemic hosts, long duration of host-parasite interactions permitted hyperspecialized mites with allometric deformations (body wider than long, strengthening of posterior legs...). Examples: the endemic species or relict populations on Nactus Kluge 1983; or Bavaya Roux 1913... (Bertrand 1987, Bertrand et al. 2008). The apomorphies denote a common origin, and are rooted in the past, or contrarily, are they solely due to independent evolution i.e. convergence? The scale like setae are more differentiated than simple ones, is the differentiation evidently prior to the host divergence?

b) Which are the more helpful criteria for reconstruction of the geckobian history? The body shape, the scutum (well delimited or not), the 
ocular plates (size, connected to the scutum or free).... help to recognize and identify the species with ease. The leg chaetotaxy (number and shape of setae) is the more integrative criteria and has been privileged because chaetotaxic analysis had given hope to help in a comprehensive ordination of the species: Jack (1964) established several "groups" of species, and the chaetotaxy opened the door to phylogenetic hypothesis based on general axioms elaborated through François Grandjean's principles (Jack, 1964). However, this classification is descriptive and naturally limited by the few setae on each of article, the constancy of this number on genua. The Jack's groups are useful, but they cannot be taken as absolute evidence of phylogenetic relationships, because identical pattern may result from different processes (Bertrand et al. 1995). Contrarily, when some apomorphic characters are shared by several species belonging to the same chaetotaxic group, a common origin may be suspected, and if the hosts are phylogenetically close, the radiation becomes highly probable.

Concluding remarks: pending questions and paths for future research on the Mediterranean geckobians, the genus Tarentola, and the Gekkonidae

a) The Mediterranean host Tarentola spp.: The geckoes are differentiated since a long time as it is attested by the fossil gekkotans identified during the Mesozoic (Cretaceous: BorsukBiałynicka, 1990, Arnold and Poinar, 2008) that is revealed by the distribution Gamble et al. 2008b. Even if the scale mites have indeed switched from insects to vertebrates more than $200 \mathrm{My}$ ago, as speculated by Bochkov and O'Connor (2006), the Reptilian Mediterranean hosts were already available. Recent studies showed that in Mediterranean Region, the Gekkotans diverged at least since Miocene crisis because of the fragmentations of the distribution. Consecutively, the comprehension of the taxonomy of the genus Tarentola was improved by identification of some vicariant subspecies (Moroccan, Tunisian...) (Carranza et al. 2002, Geniez et al. 1999, Joger and Bshaenia, 2010). So, an updating "which hosts with which parasite" becomes more and more suitable now.

b) The "two" historic parasites of Tarentola spp.: two species latastei and loricata were described on this host around the Mediterranean Basin and they can parasite simultaneously on the same individuals of this wall-gecko, one being preferably fixed between the toes, and the second on other favorable parts of the host's body. On the other hand, since the Berlese's description (1892), we know that the intimate interactions of the highly specialized by ectoparasitic mites obliged the parasite to a strict stenoxeny (Hirst, 1926, Bochkov and Mironov, 2000). This observation of two species sharing the same individual popularized the thought that some species are heteromorphic (Hirst, 1926). More recently, Girot (1969) demonstrated that two true species can indeed share T. mauritanica: two geckobians of different lineages, one of them with ventral scale like setae, have succeeded, independently, in adaptation to the same host. Note that whereas geckobians colonized the five continents, and even if the host Tarentola is also present in the Americas (Jamaica, Cuba...), none of the species described in the New World possesses "scale-like ventral setae" (orally confirmed by Ricardo Paredes Leon, pers. com.). Contrarily, several species around the Mediterranean Basin exhibit such ventral setae.

c) The Mediterranean geckobians with scale like setae

As the Maltese new species, several Mediterranean geckobians exhibit a central part of the ventral surface that is covered by scale-like setae. These special shaped setae have been described notably on G. loricata Berlese, 1892 in the Western Basin of the Mediterranean Sea, and on G. tarentulae Trägårdh, 1905, parasite of the Egyptian Tarentola annularis (Geoffroy-de-Saint-Hilaire, 1827). 
Species with these special ventral setae have been found also on the Canary Islands: Geckobia tinerfensis and G. canariensis, parasites of Tarentola delalandei Steindachner, 1891; T. boettgeri Joger and Bischoff, 1983 and T. gomeriensis Joger and Bischoff, 1983 (Zapatero-Ramos et al., 1989). Other geckobians with such setae were identified in Asian, and around the Mediterranean Region (Bertrand et al., 1999, Bertrand et al. in press): these species are not parasitic on Phyllodactylidae but on Gekkonidae.

These data underline that new directions for researches with Pterygosomatids are now opened. This way is parallel to the development of the more modern data on the host populations (Carranza et al. 2002, Carranza and Arnold, 2006) . Further research could offer the opportunities to test the possible common of Eastern and Western geckobians with ventral scale setae.

Updated keys for Pterygosomid mites: Identification of the genera (Key 1), Keys to the main groups of the genus Geckobia Mégnin (Key 2) and Key of the Mediterranean species with scale like setae (Key 3) (improved from Bertrand, Modry and Cole 2008).

\section{Key 1: Pterygosomatidae: Key to the genera.}

1. Leg I with 3 or more femoral setae, body usually longer than wide or rounded ................. 2 - Three or less than 3 femoral setae, dorsum usually with dense setae, body rounded, or as wide as long, or wider than long.................... 5

2. Body soft, not leathery $\ldots \ldots \ldots \ldots \ldots \ldots \ldots$ - Skin leathery, large species, five genual setae on legs I to IV. All legs with three femoral setae. South African.................... Ixodiderma Lawrence — Body wider than long, only 2 to 4 genual setae on legs I, South African species.... Scaphothrix Lawrence

3. With few long dorsal setae, parasitic on Iguanidae..........................4 — Very long dorsal setae inserted on platelets (1213 pairs), may be found on Arthropods........... Pimeliaphilus Trägårdh
- With numerous dorsal setae, movable digit hooklike, American ................. Geckobiella Hirst

4. Dorsal setae short, placed in rows, with or without median dorsal plates, inverse pear-shaped scutum with contiguous ocular plates, West Indies, Cuba on Cyclura sp......... Cyclurobia De La Cruz - Thirteen, 14 or 15 pairs of dorsal setae, parasite on reptiles ................... Hirstiella Berlese — The genus Bharatoliaphilus Prasad 1975 was mentioned from India from Dove and described on an unique specimen.

5. Dorsal scutum absent, eyes lacking, few setae on ventral side, no spurs on coxae, no lateral setae on tibia II, III and IV ..........................6 - Dorsal scutum present, entire or divided, eyes usually present, usually 5 setae on tibia (leg I to IV)

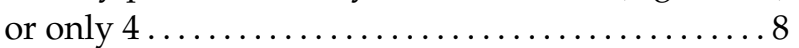

6. Body usually wider than long : typically hosted by Agamidae, Pterygosoma Peters, two sub-genera .

.

- Round in shape, with numerous dorsal setae, on South African Lizards......... Zonurobia Lawrence

7. Four setae on genu leg I.

sub-genus Gerrhosaurobia

— Less than 4 setae on genu leg I............. .........................sub-genus Pterygosoma

8. Glabrous genua by legs II-III; dense ventral setae (sometimes scale-like), stout setae at least on coxal plates; Typically on Gekkotans.... Geckobia Mégnin - Genu leg III with setae, palptibia with tuft filamentous seta; on Xantusiidae (Mexico y Central America)....... Tequisistlana Hoffmann \& Sanchez

Key 2: genus Geckobia.

Key to the main groups of species and to the major species of the Mediterranean Region (Jack 1964, Bertrand et al. 2008 updated)

1. Five tibial setae on PI, PII, PIII, PIV .......... 2 — Only four tibial setae at PI, PII \& PIII .......... 
Jack's group 3: South African species

2. Dorsal genual seta on PI and PIV absent or

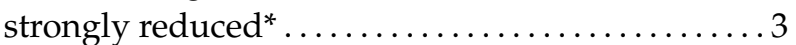
- One genual seta on leg I and IV, or only on genu PI................................ 5

3. No seta on leg trochanter IV G. keegani

- One seta on each leg trochanter... $\ldots 4$

4. Genua legs I and IV nude

G. bataviensis $(=$ G. gleadovania $)$ ?

- Not as above, femur leg I with two setae.

G. oedurae

5. Femur leg I with 3 setae $\ldots \ldots \ldots \ldots \ldots \ldots 6$

— Femur leg I with 2 setae .............. 10

6. One seta on femur leg III .............. 10

- Not as above, two setae on femur leg IV ...... 7

7. Genu leg I nude. G. diversipilis

- Genu leg I with one seta... ..8

8. No genual seta on leg IV . G. indica (and Asian species) Group 4 - One genual seta on legs I and IV, two (or three $=G$. boulangeri) femoral setae PII-IV .

....... Jack's group 1 (primitive leg chaetotaxy) 9

9. Epimeral plates (coxae) IV with two or three setae, no ventral scale like setae

Jack's group1 $\left(1^{\text {st }} \text { pars }\right)^{\text {st }}$

- Coxae IV with 3 setae, central ventral surface covered with scale like setae.

Jack's group1 (2 $2^{\text {nd }}$ pars $)^{\text {nd }} 12$

10. One or no seta on genu I, one or no seta on genu IV, two or three setae on coxa IV ............... Group2: Australian group species including Diplodactylinae parasites

- One or two femoral setae on legs II-IV ... .11
11. Only one femoral seta on legs II \& III, one genual seta on legs I \& IV, ventral scale like setae

G. australis

— Two setae on femur II-IV 12

12. Ventral setae normal, on Phyllodactylidae...... G. latastei

- Ventral setae scale like, African, Mediterranean or Asian species.....................13

13. South African species. G. ovambica

- Mediterranean or Asian species ... (Group1, Subgroup with ventral scales) 14

Key 3: genus Geckobia.

Key to the main Mediterranean species with scale like setae

1. On Gekkonidae.......................5

- On Phyllodactylidae (Tarentola spp.). Seta $\mathrm{tlm}$ on tarsi I ............................... 2

2. Scutum $W$ shaped, more than 7 pairs of scutal setae, only 3or 2 setae on inter-epimeral zone (between coxae II and III) . G. estherae - Scutum obsolescent or less visible 3

3. Less that 7 pairs of scutal setae, total of 4 setae on coxae III and IV .................... tinerfensis - coxae III and IV with 3 and 2 coxal setae in respect...........................

4. Ventral scales rounded .............. loricata

- Ventral scales leaf-like............. . canariensis

- Ventral setae fan-like.

G. tarentulae

5. Dorsal chaetotaxy preserving the lateral fields of dorsum. G. turkestana — Three or 2 femoral setae PI .6

6. Two femoral setae................ squamaeum - Three femoral setae on P1, two on PII, PIII, PIV . 7 
7. Reduced setae alm on tarsi I........ G. parvulum - Not reduced tarsal setae, $(\mathrm{tlm})$ absent, coxae II and III separated by more than 5 setae.......... .G. sherygini (this species from Crimean lizards is described in an other article : Bertrand et al. 2012, in press)

\section{ACKNOWLEDGEMENTS}

A.S. wishes to thank Esther Sciberras, Jeffrey Sciberras and Romario Sciberras for continuous assistance in field visits.

\section{REFERENCES}

Arnold E.N., Poinar G. 2008 - A 100 million year old gecko with sophisticated adhesive toe pads preserved in amber from Myanmar — Zootaxa, 1847: 62-68.

Bauer A.M., Jackman T.R., Greenbaum E., Gamble T. 2008 - Herpetologia Sardiniae: 59-62. Corti C. (ed.) Soc. herpetol. Ital. Belvedere, Latina, "Le Scienze" 8: 504 p.

Berlese A. 1892 - Acari, Myriapoda, et Scorpiones hucusque in Italia reperta. - Padova, Fasc. 1, p101.

Bertrand M. 1987 - Contribution à la connaissance des Pterygosomatidae du Pacifique Sud - Acarologia, 28: 241-250.

Bertrand M., Cole N., Modry D. 2008 - Adaptation in parasitic mites : Spread by the host or stay with the host? - In: Integrative Acarology Proc. $6^{\text {th }}$ European Congress EURAAC Montpellier 2008 ISBN 9782-9532656-0-6, Bertrand M., Kreiter S., McCoy K.D., Migeon A., Navajas M., Tixier M.S. and Vial L. Eds.: 137-146.

Bertrand M., Ineich I. 1989 - Répartition des Pterygosomatidae ectoparasites du Gecko Gehyra oceanica (Lesson, 1830) en Polynésie française - Acarologia, 28(3): 241-250.

Bertrand M., Paperna, I, Finkelman S. 1995 - Etudes préliminaire du genre Pterygosoma Peters, 1849 (Actinedida: Pterygosomidae): compléments à la description de Pterygosoma bibronii Jack, 1962 et notes sur les caractères évolutifs des Pterygosomidae - Acarologia, 36(2): 133-143.

Bertrand M., Paperna I., Finkelman S. 1999 - Pterygosomatidae: descriptions et observations sur les genres Pterygosoma, Geckobia, Zonurobia et Hirstiella (Acari: Actinedida) — Acarologia, 49(3): 275:304.

Bertrand M., Pogrebnyak S., Kukushin O. Submitted Host parasite relationships analysis: A Geckobian
(Raphignathoidea: Pterygosomatidae: Geckobia) parasitic of Crimean populations of Mediodactylus kotschyi (Reptilia: Gekkota) - Vestnik Zoologii.

Bochkov A.V., Mironov S.V. 2000 - Two new species of the genus Geckobia(Acari: Pterygosomatidae) from geckons (Lacertilia: Gekkonomorpha) with a brief review of host parasite associations of the genus - Russ. J. Herpetol., 7(1): 61-68.

Bochkov A.V., O'Connor B.M. 2006 - A review of the external morphology of the family Pterygosomatidae and its systematic position within the Prostigmata Acari: Acariformes -Parazitologiya+. MayJune, 40(3):201-14. [Article in Russian]

Boots M., Best A., Miller R.M. White A. 2009 — The distribution of the parasite depends essentially on the host distribution. The role of ecological feedbacks in the evolution of host defense: what does theory tell us? — Phil. Trans. R. Soc., B. 9, Vol. 364, no. 1513: 27-36.

Borsuk-Białynicka M. 1990 - Gobekko cretacicus gen. et sp. n., a new gekkonid lizard from the Cretaceous of the Gobi - Acta Palaeontol. Pol., 35(1-2): 67-76.

Carranza S., Arnold E.N., Mateo J.A., López-Jurado L.F. 2000 - Long-distance colonization and radiation in gekkonid lizards, Tarentola (Reptilia: Gekkonidae), revealed by mitochondrial DNA sequences - Proc. R. Soc. Lond. B., Biol. Sci., 267(1444): 637-649. doi:10.1098/rspb.2000.1050

Carranza S., Arnold E.N. 2006 - Systematics, biogeography and evolution of Hemidactylus geckos (Reptilia: Gekkonidae) elucidated using mitochondrial DNA sequences - Mol. Phylogenet. Evol., 38: 531-545. doi:10.1016/j.ympev.2005.07.012

Carranza S., Arnold E.N., Mateo J.A., and Geniez P. 2002 - Relationships and evolution of the North African geckos, Geckonia and Tarentola (Reptilia: Gekkonidae) based on mitochondrial and nuclear DNA sequences - Mol. Phylogenet. Evol., 23(2): 244-256. doi:10.1016/S1055-7903(02)00024-6

Gamble T., Bauer A.M., Colli G.R., Greenbaum E., Jackman T.R., Vitt L.J. and Simons A.M. 2010 - Coming to America: multiple origins of New World geckos J. Evol. Biol. 24(2):1-14.

Gamble T., Bauer A.M., Greenbaum E., Jackmann T.R. 2008a - Out of the Blue: a novel, trans-Atlantic clade of geckos (Gekkota, Squamata) - Zool. Scr., 37(4): 355-366. doi:10.1111/j.1463-6409.2008.00330.x

Gamble T., Bauer A.M., Greenbaum E., Jackmann T.R. $2008 \mathrm{~b}$ - Evidence for Gondwanan vicariance in an ancient clade of gecko lizards.- J. Biogeogr., 35: 88-104.

Geniez P., Escatllar J., Crochet P.A., Mateo J.A., Bons J. 1999 - A new form of the genus Tarentola from northwestern Africa (Squamata: Sauria: Gekkonidae) Herpetozoa 12(3/4): 187-194. 
Gil-Collado J., Rivas-López L.I., Zapatero-Ramos L.M. 1985 - Pterigosomidae (Acari; Actinedida) parásitos de Geckonidae de la Península Ibérica - Actas II Congr. Iberico Entomol., 1: 379-38.

Girot B. 1969 - Etude du cycle de Geckobia loricata et Geckobia loricata, Acariens parasites du Gecko Tarentola mauritanica - Vie et Milieu, 19: 63-141.

Goux L. 1947 - Contribution à l'étude des métamorphoses de Geckobia loricata Berl., acarien parasite du gecko Tarentola mauritanica Luc. - Bull. Mus. Hist. nat., Marseille, 7: 187-193.

Haitlinger R. 2004 - Geckobia latasti Megnin, 1878 and G. loricata Berlese, 1892 (Acari: Prostigmata: Pterygosomatidae), new mite species to the fauna of Balearic Islands, Spain - Bolleti de la Societat d'Historia Natural de les Balears, 47: 23-24.

Harris D.J., Batista V., Lymberakis P., Carretero M. A. 2004 - Complex estimates of evolutionary relationships in Tarentola mauritanica (Reptilia: Gekkonidae) derived from mitochondrial DNA sequences - Mol. Phylogenet. Evol., 30: 855-859. doi:10.1016/S10557903(03)00260-4

Hirst A.S. 1926 - On parasitic mites of the suborder Prostigmata (Trombidioidea), on lizards - J. Linn. Soc-Lond., 36: 173-200.

Hoffmann A., Morales Malacara J.B. 1985 - Una nueva especie de Geckobia (Acarida: Pterygosomatidae) colectada en México - Anal. Inst. Biol. (UNAM), Zoologia 56(1): 23-30.

Jack K.M. 1964 - Leg-chaetotaxy with special reference to the Pterygosomidae (Acarina) — Ann. Natal. Mus. 16: 152-171.

Joger U., Bshaenia I. 2010 - A new Tarentola subspecies (Reptilia: Gekkonidae) endemic to Tunisia - Bonn. Zool. Bull., 57(2): 267-274

Joger U. 1984 - Morphologische und biochemismimmunologische Untersuchungen zur Systemetic und Evolution der Gattung Tarentola (Reptilia: Gekkonidae) - Zoolog. Jahrb., 112. P. 137 - 256.
Joger U., Bischoff W. 1983 - Zwei neue taxa der gattung Tarentola(Reptilia: Sauria: Gekkonidae) —Bonn. Zool. Beitrg., 34: 459-468.

Lawrence R.F. 1953 - Two new scale-mite parasites of lizards - P. Un. St. Nat. Mus. Washington, 103(3312): 9-18.

Martinez Rivera C.C., Gonzalez-Negron A., Bertrand M., Acosta J. 2003 - Hemidactylus mabouia (Sauria: Gekkonidae), host of Geckobia hemidactyli (Actinedida: Pterygosomatidae), throughout the Caribbean and South America - Caribb. J. Sci., 39(3): 321-326.

Sciberras A. 2007 — Lizards at Id-Dwejra - Dwejra Heritage Park Gozo, Dwejra Management Board: 28-33.

Trägårdh I. 1904 - Results Swedish Zoological Expedition to Egypt and the White Nile 1901. Acariden aus Aegypten und dem Sudan, 20: 1-124.

Vidal K., Hedges S.B. 2009 — Lizards, snakes and amphisbaenias (Squamata) - The time tree of life Hedges and Kumar Eds. C. R. Biologies, Oxford University Press, 332: 129-139.

Willmann C. 1955 - Eine Ausbeute ParasitisherAcari von Kleinsaûgern auf Sizilien. — Parasitol. Res. (Z. f. Parasitenkunde), 17: 175-184.

Zapatero-Ramos L.M., González-Santiago P.M., SoleraPuertas M.A., Carvajal-Gallardo M.M. 1989 — Estudio de nuevas especies de Pterigosomidae (Acari: Actinedida) sobre geckónidos de las Islas Canarias. Descripción de Geckobia canariensis n. sp. Rev. Ibér. Parasitol., 49(1): 51-64

\section{COPYRIGHT}

$((c)$ EY-NC-ND Bertand M. et al. Acarologia is under free license. This open-access article is distributed under the terms of the Creative Commons-BY-NC-ND which permits unrestricted non-commercial use, distribution, and reproduction in any medium, provided the original author and source are credited. 